\title{
Mung bean as food source for breastfeeding women with diabetes mellitus in Indonesia: carbohydrate profiles at different soaking times
}

\author{
*Widjajaseputra, A.I., Widyastuti, T.E.W. and Trisnawati, C.Y. \\ Food Technology Department, Widya Mandala Catholic University Surabaya, Jl. Dinoyo 42-44 Surabaya \\ 60265, East Java, Indonesia
}

\begin{abstract}
Article history:
Received: 28 May 2019

Received in revised form: 26

June 2019

Accepted: 2 July 2019

Available Online: 6 July 2019

Keywords:

Mung bean,

Soaking time,

Carbohydrate profile,

Breastfeeding-women with

$\mathrm{DM}$
\end{abstract}

DOI:

https://doi.org/10.26656/fr.2017.3(6).209

\begin{abstract}
The study reported carbohydrate profiles of mung bean that was soaked for different times, and how the bean can be a potential food in Indonesia for breastfeeding women with diabetes mellitus (DM). This study used a single factor with completely randomized design. The soaking time was a factor with five levels; 0 (control), 2, 4, 6, and $8 \mathrm{hrs}$. Each treatment level was replicated three times. Observed dependent variables of carbohydrate profiles were starch, amylose, total sugar, total dietary fiber (TDF), insoluble dietary fiber (IDF), soluble dietary fiber (SDF), and resistant starch (RS) contents. The results were subjected to one-way ANOVA and least significant difference test at $\mathrm{p}<0.05$ using SPSS (version 19). The soaking time resulted in a decrease of the starch content, relatively unchanged amylose content, and an increase of the reducing sugar content. The TDF tended to decrease, the RS was significantly $(p<0.05)$ higher than the unsoaked mung bean from $4 \mathrm{hrs}$ of soaking and the SDF tended to increase with soaking. Generally, the digestible (total sugar) and indigestible (total dietary fiber and resistant starch) carbohydrates increased during the soaking. The overall results would indicate fewer calories and inhibition of blood sugar increases that are beneficial to breastfeeding women with DM. The findings provide a new scientific understanding of mung bean as an alternative food source for breastfeeding women with diabetes mellitus and can contribute to formulating national and global DM management food policy.
\end{abstract}

\section{Introduction}

Mung bean (Vigna radiata $\mathrm{L}$ ), green gram or golden gram, is the third most cultivated legume in Indonesia after soybeans and peanuts (Purwono and Hartono, 2005). In 2015, mung bean production (dry seed) in Indonesia was about 271,000 MT compared to soybean production of about 963,000 MT (BPS-Statistics Indonesia, 2016). With its quantity of protein content being second to its carbohydrate content, mung bean can be used as a source of proteins, and it is also a good source of dietary fiber, essential minerals, and vitamins (Oghbaei and Prakash, 2017). As a legume, mung bean is important in human nutrition, but this can be limited because of its antinutrients such as protease inhibitors, phytic acid, and flatulence-causing oligosaccharides (Hussain and Burhanuddin, 2011). Mung bean carbohydrate content is $50-60 \%$ (Tang et al., 2014) with starch being its most abundant carbohydrate at $37 \%$ with amylose fraction of about $32 \%$ and amylopectin fraction of about $68 \%$ (Sandhu and Lim, 2006). Mung bean starch granules have a round to oval shape and $7 \mu \mathrm{m}-28$ $\mu \mathrm{m}$ in size (Hongsprabhas, 2006).
Prior to use, mung bean is usually soaked first to reduce its antinutrients (Kaur et al., 2015). During soaking, water entered the bean, its tissues hydrated, and some enzymes can be activated to extents that are dependent on the soaking times culminating in minor and major changes in the bean structures and components. These changes will increase the digestibility of mung bean as a food source. In Indonesia, mung bean is a traditional food source for women that are breastfeeding, as it is believed that the consumption of mung bean porridge improved the quality of breast milk due to viscosity increases from the mung bean starch. However, starch is associated with lifestyle diseases, notably diabetes, which is projected globally to afflict $54 \%$ more adults in 2030, and individuals with diabetes in Indonesia are projected to increase from 7 million in 2010 to 12 million in 2030 (Whiting et al., 2011; Sopade, 2017a). Hence, if breastfeeding women are diabetic, their consumption of starch-containing diets needs to be regulated with the overall aim of managing DM among Indonesians, for example. Therefore, this study examined the effects of soaking time on 
carbohydrate profiles of mung bean for understanding the potential of the bean as a good food source for breastfeeding women with DM.

\section{Materials and methods}

\subsection{Materials}

Commercial mung bean was obtained from a local market in Surabaya, East Java, Indonesia. All the chemicals, standards and reagents were of analytical grade.

\subsection{Soaking procedure}

According to Widjajaseputra et al. (2019), the mung bean was sorted, and only intact and sound grains were washed and soaked $(1: 5 \mathrm{w} / \mathrm{v})$ in distilled water at $30^{\circ} \mathrm{C}$ for 0 (control), 2, 4, 6 and $8 \mathrm{hrs,} \mathrm{after} \mathrm{which} \mathrm{the} \mathrm{grains}$ were drained and freeze-dried (Bluewave B-10B Vacuum Freeze Drier; China) to 2-3\% moisture content. The dried grains were ground (Miyako, Indonesia), wrapped in an airtight plastic container and aluminum foil bag as secondary packaging, and then stored in a refrigerator (LG, Indonesia) at $5 \pm 1^{\circ} \mathrm{C}$ until analyzed. The soaking experiment was replicated thrice.

\subsection{Proximate analysis}

Moisture and ash contents by thermogravimetry, protein analysis by micro Kjeldahl, fat analysis by Soxhlet method, and carbohydrate by difference were done following standard procedures (AOAC, 2010).

\subsection{Carbohydrate profile}

Starch and total sugar were measured using the Nelson Somogyi method (AOAC, 2010), in which the reducing sugar in the sample reduced cupric oxide to copper oxide, which was reacted with arsenomolybdate to form a blue complex that was spectrophotometrically (Shimadzu, UV-Vis 1800 Spectrophotometer, Japan) quantified at $540 \mathrm{~nm}$ wavelength from a standard absorbance curve. Amylose levels were measured following the procedure in Juliano (1971). Total dietary fiber (TDF), soluble dietary fiber (SDF) and insoluble dietary fiber (IDF) contents were determined by a multienzymatic gravimetric method (Asp et al., 1983), whereby starch and protein were digested with enzymes to small fragments to separate the fiber, before separating the IDF from the SDF by filtering and washing the residues with water. The IDF as the remaining residue was recovered by precipitation with 95\% ethanol and washed with acetone. Resistant starch (RS) was analyzed using the method of Goni et al. (1996) that involves the removal of proteins and digestible starches, solubilization and enzymatic hydrolysis of RS and its quantification from the glucose released.

\subsection{Statistical analysis}

The experimental design used in this study was a single factor completely randomized design. Data are expressed as mean \pm standard deviation (SD) for the three in each group $(n=3)$. The data were subjected to one-way ANOVA $(\mathrm{p}<0.05)$ with a least significant difference (LSD) test at $\mathrm{p}<0.05$ using SPSS (version 19) for comparative analysis.

\section{Results and discussion}

\subsection{Proximate analysis}

As expected, the moisture content of the mung bean significantly $(\mathrm{p}<0.05)$ increased $(12-53 \mathrm{~g} / 100 \mathrm{~g}$ wet basis) with the soaking (Table 1) as the grains imbibed water and the cells were hydrated (Nonogaki et al., 2010). The penetration of water into the grains would affect biochemical reactions in the grains as hydrolyzing enzymes became active, and $\alpha$-amylase, invertase, lipase, and protease have been reported to be activated (Rahman et al., 2007; Fayyaz et al., 2018) thereby affecting the mung bean starch, protein and fat components. The protein content of the unsoaked mung bean $(23.39 \mathrm{~g} / 100$ $\mathrm{g}$ wet basis or $26.64 \mathrm{~g} / 100 \mathrm{~g}$ dry weight basis) is similar (27.5 g/100 g dry weight basis) reported by Mubarak (2005). Table 1 shows the significant $(p<0.05)$ changes in fat and ash components of the mung bean with the fat content tended to increase, while the ash content decreased along with the longer soaking time. Various

Table 1. Effect of soaking time on the proximate composition of the mung bean

\begin{tabular}{cccccc}
\hline $\begin{array}{c}\text { Soaking } \\
\text { Time }\end{array}$ & $\begin{array}{c}\text { Moisture content } \\
(\mathrm{g} / 100 \mathrm{~g} \text { wet basis })\end{array}$ & $\begin{array}{c}\text { Protein } \\
(\mathrm{g} / 100 \mathrm{~g} \text { wet basis })\end{array}$ & $\begin{array}{c}\text { Fat } \\
(\mathrm{g} / 100 \mathrm{~g} \text { wet basis })\end{array}$ & $\begin{array}{c}\text { Ash } \\
(\mathrm{g} / 100 \mathrm{~g} \text { wet basis })\end{array}$ & $\begin{array}{c}\text { Carbohydrate } \\
(\mathrm{g} / 100 \mathrm{~g} \text { wet basis })\end{array}$ \\
\hline P0 & $12.18 \pm 0.46^{\mathrm{a}}$ & $23.39 \pm 2.16$ & $2.56 \pm 0.36^{\mathrm{b}}$ & $4.35 \pm 0.06^{\mathrm{b}}$ & $57.52 \pm 2.92^{\mathrm{e}}$ \\
P1 & $20.66 \pm 0.77^{\mathrm{b}}$ & $22.80 \pm 1.32$ & $1.72 \pm 0.14^{\mathrm{a}}$ & $4.33 \pm 0.09^{\mathrm{b}}$ & $50.49 \pm 1.95^{\mathrm{d}}$ \\
P2 & $32.60 \pm 0.38^{\mathrm{c}}$ & $23.56 \pm 0.89$ & $4.02 \pm 0.18^{\mathrm{c}}$ & $4.20 \pm 0.11^{\mathrm{b}}$ & $35.62 \pm 0.98^{\mathrm{c}}$ \\
P3 & $51.03 \pm 0.48^{\mathrm{d}}$ & $23.26 \pm 1.07$ & $5.22 \pm 0.14^{\mathrm{e}}$ & $3.95 \pm 0.19^{\mathrm{a}}$ & $16.54 \pm 1.36^{\mathrm{b}}$ \\
P4 & $53.00 \pm 0.58^{\mathrm{e}}$ & $24.55 \pm 0.59$ & $4.43 \pm 0.18^{\mathrm{d}}$ & $3.98 \pm 0.09^{\mathrm{a}}$ & $14.04 \pm 0.58^{\mathrm{a}}$ \\
\hline
\end{tabular}

Values are means \pm standard deviations $(n=3)$. Different alphabet superscripts in the same column showed a significant difference based on the LSD Test $(\mathrm{p}<0.05)$.

$\mathrm{P} 0=$ control (without soaking), $\mathrm{P} 1=2$ hours, $\mathrm{P} 2=4$ hours, $\mathrm{P} 3=6$ hours, $\mathrm{P} 4=8$ hours. 
Table 2. Effect of soaking time on the carbohydrate profiles of the mung bean

\begin{tabular}{|c|c|c|c|c|c|c|c|}
\hline $\begin{array}{l}\text { Soaking } \\
\text { Time }\end{array}$ & $\begin{array}{l}\text { Starch } \\
\text { (g/100 g dry } \\
\text { weight basis) }\end{array}$ & $\begin{array}{c}\text { Amylose } \\
\text { (g/100 g dry } \\
\text { weight basis) }\end{array}$ & $\begin{array}{l}\text { Total sugar } \\
\text { (g/100 g dry } \\
\text { weight basis) }\end{array}$ & $\begin{array}{l}\text { Total dietary } \\
\text { fiber } \\
\text { (g/100 g dry } \\
\text { weight basis) }\end{array}$ & $\begin{array}{c}\text { Insoluble dietary } \\
\text { fiber } \\
\text { (g/100 g dry } \\
\text { weight basis) }\end{array}$ & $\begin{array}{l}\text { Soluble dietary } \\
\text { fiber } \\
\text { (g/100 g dry } \\
\text { weight basis) }\end{array}$ & $\begin{array}{l}\text { Resistant starch } \\
\text { (g/100 g dry } \\
\text { weight basis) }\end{array}$ \\
\hline P0 & $30.74 \pm 3.39^{\mathrm{e}}$ & & & $30.80 \pm 0.71^{\mathrm{c}}$ & $25.98 \pm 0.87^{\mathrm{c}}$ & $4.82 \pm 0.16^{\mathrm{a}}$ & \\
\hline $\mathrm{P} 1$ & $24.38 \pm 0.27^{\mathrm{d}}$ & $33.09 \pm 1.18$ & & $38.30 \pm 0.08^{\mathrm{d}}$ & $28.99 \pm 0.03^{\mathrm{d}}$ & $9.30 \pm 0.11^{\mathrm{e}}$ & $8.33 \pm 0.09^{\mathrm{a}}$ \\
\hline $\mathrm{P} 2$ & $22.22 \pm 0.46^{\mathrm{c}}$ & $33.06 \pm 3.42$ & $29.52 \pm 0.86^{\mathrm{c}}$ & $27.65 \pm 0.57^{\mathrm{b}}$ & $21.12 \pm 0.32^{\mathrm{b}}$ & $6.53 \pm 0.06^{\mathrm{b}}$ & $18.49 \pm 0.27^{\mathrm{e}}$ \\
\hline P3 & $18.81 \pm 0.44^{\mathrm{b}}$ & $34.55 \pm 0.43$ & $34.91 \pm 0.58^{\mathrm{d}}$ & $24.80 \pm 0.35^{\mathrm{a}}$ & $17.95 \pm 0.29^{\mathrm{a}}$ & $6.86 \pm 0.06^{\mathrm{c}}$ & $14.49 \pm 0.06^{\mathrm{d}}$ \\
\hline P4 & $15.81 \pm 2.22^{\mathrm{a}}$ & $35.22 \pm 3.25$ & $39.52 \pm 2.47^{\mathrm{e}}$ & $24.59 \pm 0.06^{\mathrm{a}}$ & $17.48 \pm 0.08^{\mathrm{a}}$ & $7.11 \pm 0.02^{\mathrm{d}}$ & $13.65 \pm 0.19^{c}$ \\
\hline
\end{tabular}

Values are means \pm standard deviations $(n=3)$. Different alphabet superscripts in the same column showed a significant difference based on the LSD Test $(\mathrm{p}<0.05)$.

$\mathrm{P} 0=$ control (without soaking), $\mathrm{P} 1=2$ hours, $\mathrm{P} 2=4$ hours, $\mathrm{P} 3=6$ hours, $\mathrm{P} 4=8$ hours.

studies (Desalegn, 2015; Fayyaz et al., 2018) had measured the increase in the fat content of grains with soaking, which they related to the synthesis of the fat as a catabolic ingredient for growth.

Decreasing in ash content can be due to the use of certain minerals for the synthesis of several compounds that were needed to prepare germination such as $\mathrm{Ca}$ for the activation of amylase, $\mathrm{Mg}$ was needed for chlorophyll synthesis, $\mathrm{PO}_{4}^{-3}$ was needed for energy metabolism. The reduction in the ash content with the soaking could have resulted from the leaching of relevant soluble components from the mung bean with time (D’Souza, 2013).

\subsection{Carbohydrate profile}

Carbohydrates are the largest component of mung beans that need to be studied for their quantity and type or source is related to their potential as a source of calories for people with diabetes mellitus. Besides the amount of carbohydrate ingested, the type of carbohydrate also affects postprandial responses (American Diabetes Association, 2008). Foods with high resistant starches and amylose contents have been shown to exhibit slow rates of digestibility and reduced energy intakes by the intestinal cells, evident by low glycemic indices (Vatanasuchart et al., 2009; Sopade, 2017b).

The starch content of the control sample (30.74 $\mathrm{g} / 100 \mathrm{~g}$ dry weight basis), significantly $(\mathrm{p}<0.05)$ reduced with the soaking time (Table 2), which did not significantly affect $(\mathrm{p}>0.05)$ the amylose content (32.56 $35.22 \mathrm{~g} / 100 \mathrm{~g}$ dry starch). The increase in the total sugars with the soaking time (Table 2) could suggest that the mung bean starch changed into simpler compounds during the soaking due to the activity of $\alpha$-amylase, being the dominant amylase in mung beans (Patong and Suarni, 2007). It is plausible that the solids lost during the soaking through leaching, though minimal, could contribute to the increases measured for these and other parameters.

The total dietary fiber (TDF) decreased with the longer soaking time and ranged from 38.30-24.59 g/100 $\mathrm{g}$ dry weight basis (Table 2), with the seed coats or hulls contributing much of the soluble and insoluble fibers. Soluble dietary fiber (SDF) lowers the blood glucose level (Aguilera et al., 1993). Chandalia et al. (2000) concluded that a high intake of dietary fiber, particularly of the soluble type, above the level of the recommendation by the American Diabetes Association, improved glycemic controls in patients with type 2 diabetes. Generally, with the mung bean, the insoluble dietary fiber (IDF) tend to decrease with the longer soaking (Table 2), which the SDF tend to increase. Possibly, hydrolytic enzymes degraded the TDF, solubilized a part of the IDF to yield more SDF as the soaking progressed beyond two hours. The resistant starch (RS) measured for the control mung bean $(11.12 \pm 0.10 \mathrm{~g} / 100 \mathrm{~g}$ dry weight basis) is similar to reported data (about 11\%) by Guillon and Champ (2002), and upon soaking, this initially reduced after two hours before increasing. There are five types (RS1 = RS5) of resistant starches (Sopade, 2017b), and type RS2 is predominant in legumes as legume starches are physically enclosed within intact cell (protein) structures (Kaur et al., 2015; Sopade, 2017b). Such starches are indigestible by human digestive enzymes in the small intestine and pass to the large intestine or colon, thereby modifying postprandial glycemic responses.

\section{Conclusion}

The carbohydrate profiles showed that the soaking time decreased the starch level with relatively fixed amylose content and an increase in the total sugar levels. While the TDF tended to decrease, the RS was significantly $(p<0.05)$ higher than the unsoaked mung bean from $4 \mathrm{hrs}$ of soaking and the SDF increased with the soaking. In general, the digestible carbohydrates increased during the soaking along with an increase in several types of indigestible carbohydrates. These changes in the carbohydrate profiles of the mung bean with the soaking are expected to lead to reduced calories and a significant reduction in the blood glucose upon 
consumption of the soaked mung bean. This will benefit for breastfeeding women with DM. Further studies will investigate soaked mung bean digestibility to confirm the beneficial deductions from the present study.

\section{Acknowledgment}

Authors would thank the Directorate of Research and Community Service, Directorate General of Research and Development Strengthening, Ministry of Research; Technology and Higher Education, Republic of Indonesia, for research fund through the Decentralization Research Program of 2018 (Penelitian Dasar Unggulan Perguruan Tinggi with contract number of $115 \mathrm{O} /$ WM01.5/ N/ 2018).

\section{References}

Aguilera, E., Moreno, J. and Ferrer, M. (1993). Blood chemistry values in three Pygoscelis penguins. Comparative Biochemistry and Physiology, 105(3), 471-473. https://doi.org/10.1016/0300-9629(93) 90421-Y

American Diabetes Association. (2008). Nutrition recommendations and intervention for diabetes. Diabetes Care, 31(1), S61-S78. https:// doi.org/10.2337/dc08-S061

AOAC. (2010). Official Methods of Analysis. $18^{\text {th }}$ ed. Washington D.C.: Association of Official Analytical Chemists

Asp, N.G., Johansson, C.G., Halmer, H. and Siljestrom, M. (1983). Rapid enzymatic assay of insoluble and soluble dietary fiber. Journal of Agricultural and Food Chemistry, 31, 476-482. https:// doi.org/10.1021/jf00117a003

BPS-Statistics Indonesia (2016). Produksi Tanaman Pangan ATAP Tahun 2015. Jakarta: Badan Pusat Statistik

Chandalia, M., Garg, A., Lutjohann, D., von Bergmann, K., Grundy, S.M. and Brinkley, L.J. (2000) Beneficial effects of high dietary fiber intake in patients with type 2 diabetes mellitus. The New England Journal of Medicine, 342(19), 1392-1398.

Desalegn, B.B. (2015). Effect of soaking and germination on proximate composition, mineral bioavailability and functional properties of chickpea flour. Food and Public Health, 5(4), 108-113. https://doi.org/ 10.5923/j.fph.20150504.02

D'Souza, M.R. (2013). Effect of traditional processing methods on nutritional quality of field bean. Advances in Bioresearch, 4(3), 29-33.

Fayyaz, N., Mohebbi, M. and Milani, E. (2018). Effect of germination on nutrients, mineral, phytic acid and enzyme activity of mung bean. Acta Medica Mediterranea, 34, 597-604. http:// doi.org/10.19193/0393-6384_2018_2s_94

Goni, I., Garcia-Diz, L., Manas, E. and Saura-Calixto, F. (1996). Analysis of resistant starch: a method for foods and food products. Food Chemistry, 56(4), 445 -449. https://doi.org/10.1016/0308-8146(95)00222-7

Guillon, F. and Champ, M.M.J. (2002). Carbohydrate fractions of legumes: uses in human nutrition and potential for health. British Journal of Nutrition, 88 (3), S293-S306. http://doi.org/10.1079/BJN2002720

Hongsprabhas, P. (2006). On the gelation of mung bean starch and its composite. International Journal of Food Science and Technology, 42(1), 658-668. https://doi.org/10.1111/j.1365-2621.2006.01448.x

Hussain, I. and Burhanuddin, M. (2011). Optimization of germination conditions for germinated mung bean flour by response surface methodology. African Journal of Food Science and Technology, 2(10), 232 -239 .

Juliano, B.O. (1971). A simplified essay for milled-rice amylase. Cereal Science Today, 16, 334-340.

Kaur, M., Sandhu, K.S., Ahlawat, R.P. and Sharma, S. (2015). In vitro starch digestibility, pasting and textural properties of mung bean: effect of different processing methods. Journal of Food Science and Technology, 52(3), 1642-1648. http:// doi.org/10.1007/s13197-013-1136-2

Mubarak, A.E. (2005). Nutritional composition and antinutritional factors of mung bean seeds (Phaseolus aureus) as affected by some home traditional process. Food Chemistry, 89(1), 485-495. http://doi.org10.1016/j.foodchem.2004.01.007

Nonogaki, H., Bassel, G.W. and Bewley, J.W. (2010). Germination-still a mystery. Plant Science, 179(6), 574-581.https://doi.org/10.1016/

j.plantsci.2010.02.010

Oghbaei, M. and Prakash, J. (2017). Nutritional properties of green gram germinated in mineral fortified soak water: I. Effect of dehulling on total and bioaccessible nutrients and bioactive components. Journal of Food Science and Technology, 54(4), 871-879. https://doi.org/10.1007/ s13197-016-2382-x

Patong, R. and Suarni (2007). Potensi kecambah kacang hijau sebagai sumber enzim $\alpha$-Amilase. Indonesian Journal of Chemistry, 7(3), 332-336.

Purwono and Hartono, R. (2005). Kacang Hijau. Jakarta: Penebar Swadaya.

Rahman, M.M., Banu, L.A., Rahman, M.M. and Shahjadee, U.F. (2007). Changes of the enzymes activity during germination of different mung bean 
varieties. Bangladesh Journal of Scientific and Industrial Research, 42(2), 213-216. https:// doi.org/10.3329/bjsir.v42i2.474

Sandhu, K.S. and Lim, S.T. (2006). Digestibility of legume starches as influenced by their physical and structural properties. Carbohydrate Polymers, 71, 245-252.https://doi.org/10.1016/ j.carbpol.2007.05.036

Sopade, P.A. (2017a). Food processing and product properties, focusing on glycemia, presented at International Food Conference 2016, Surabaya: Universitas Katolik Widya Mandala Surabaya.

Sopade, P.A. (2017b). Cereal processing and glycemic response. International Journal of Food Science and Technology, 52, 22-37. https://doi.org/10.1111/ ijfs. 13237

Tang, D., Dong, Y., Ren, H., Li, L. and He, C. (2014). A review of phytochemistry, metabolite changes, and medicinal uses of the common food mung bean and its sprouts (Vigna radiata). Chemistry Central Journal, 8, 4-16. https://doi.org/10.1186/1752-153X8-4

Vatanasuchart, N., Niyomwit, B. and Wonggkrajang, K. (2009). Resistant starch contents and the in vitro starch digestibility of Thai starchy foods. Kasetsart Journal-Natural Science, 43(1), 178-186.

Whiting, D.R., Guariguata, L., Weil, C. and Shaw, J. (2011). IDF Diabetes Atlas: Global estimates of the prevalence of diabetes for 2011 and 2030. Diabetes Research and Clinical Practice, 94(3), 311-321. https://doi.org/10.1016/j.diabres.2011.10.029 